\title{
School Managers Perceptions towards Energy Efficiency and Renewable Energy Sources
}

\author{
Dimitrios Drosos ${ }^{\mathrm{a}}$, Grigorios L. Kyriakopoulos ${ }^{\mathrm{b}}$, Stamatios Ntanos ${ }^{\mathrm{a}}$, Androniki Parissi ${ }^{\mathrm{c}}$ \\ ${ }^{a}$ Department of Business Administration, School of Business, Economics and Social Sciences, University of West Attica, 250 Thivon \& P. \\ Ralli str, 12244 Egaleo, Greece. \\ ${ }^{b}$ Electric Power Division, Photometry Laboratory, School of Electrical and Computer Engineering, National Technical University of \\ Athens, 15780 Athens, Greece. \\ ${ }^{2} 2^{\text {nd }}$ Elementary School of Skydra, Fintia 1, Skydra, 58500, Greece.
}

\begin{abstract}
Global economic growth is accompanied by increased energy demand, thus conventional fuels such as coal, oil and gas, which are the primary energy sources, are gradually being depleted. At the same time, the combustion of conventional fuel for energy production causes serious adverse effects on the environment and contributes to climate change due to the emitted greenhouse gases. For the above reasons, most of the developed and developing countries especially during the last decades, have introduced various incentives for the greater penetration of renewable energy sources (RES) in all sectors of the economy. Concerning the building sector, several measures have been adopted, including the promotion of energy efficiency and energy saving. A significant proportion of the building stock are the school buildings where students and teachers spend a significant proportion of their daily time. Teachers' attitudes and views, especially the school unit managers concerning the use of RES in schools, are important in the effort to rationalize and control energy use. This study was conducted through a structured questionnaire applied to a sample of 510 school managers in Greece's primary and secondary education. The school unit managerial role for the case of Greek schools is performed by the school principal who has both administrative and educational duties. Statistical analysis included the application of Friedman's test and hypothesis test on questions concerning school manager environmental perceptions and energy-saving habits. According to the results, Greek school managers have a high degree of environmental sensitivity, since $97.6 \%$ agreed or strongly agreed that the main concern should focus on energy saving. Furthermore, $71 \%$ of the respondent reported to have good knowledge on solar energy, followed by $64 \%$ on wind energy while only $34 \%$ are knowledgeable on biomass. Almost all the respondents (99\%) agreed that it is important to provide more RES-orientated education through the taught curricula. Concerning energy saving behaviour, around $90 \%$ reported that they switch off the lights when leaving the classroom and they close the windows when the air-condition is operating. Hypothesis tests revealed a relationship between the school managers' ecological beliefs, the energy saving habits in the school environment, and the recognition of the importance of environmental education. Conclusions highlighted the need to intensify environmental education programs in the school environment concerning RES in schools. This will lead to a higher level of environmental awareness of both teachers and students and therefore to a more dynamic behaviour towards the effort to "greenify" the school environment.
\end{abstract}

Keywords: school buildings, school manager, renewable energy resources, energy efficiency, environmental sensitivity.

Article History: Received: 24 ${ }^{\text {th }}$ January 2021; Revised: $6^{\text {th }}$ March 2021; Accepted: 12 ${ }^{\text {th }}$ March 2021; Available online: $24^{\text {th }}$ March 2021

How to Cite This Article: Drosos, D., Kyriakopoulos, G.L, Ntanos, S., Parissi, A. (2021) School Managers Perceptions towards Energy Efficiency and Renewable Energy Sources. International Journal of Renewable Energy Development, 10(3), 573-584

https://doi.org/10.14710/ijred.2021.36704

\section{Introduction}

Energy is an integral part of modern economies, both for consumption and production. It is a crucial element for human development, as societies are so interconnected with energy that any disruption of energy supply has farreaching consequences for prosperity (Acharya \& Adhikari, 2021). Today, about $81 \%$ of the world's primary energy comes from fossil fuels, with oil accounting for $31.9 \%$, coal for $27.1 \%$ and gas for $22.1 \%$ (Belaïd \& Zrelli, 2019). In recent years, the energy sector has been at a transition point towards a different production and consumption model. This model is based on the principles and vision of "sustainable development", an international effort to tackle climate change by "greening" the fuel-mix, use environmental-friendly technologies and raise the environmental awareness at both international, national, and local level (Diakoulaki, 2014).

The role of education towards implementing the sustainable development concept has been systematically identified and motivated by the United Nations. A United Nations program known as Education for Sustainable Development (ESD) encouraged changes in knowledge, skills, values, and attitudes to enable a more sustainable and equitable society for all. The ESD program has been adopted since 2005 by the environment, and education ministers in European member stated, an action known as

\footnotetext{
* Corresponding author: gregkyr@chemeng.ntua.gr
} 
the UNECE Strategy for ESD (UNECE, 2005). Therefore, in 2005-2014 the UNECE Strategy tried to organize the education resources and motivate them towards the sustainable development concept. In the final review of the UNECE strategy implementation (known as the Decade of Education for Sustainable Development DESD), it was concluded that essential steps have been taken towards sustainability in education. Those steps include creating and applying new policies, changes in taught curricula in all education levels towards the environment, and creating partnerships and new networks to promote the sustainability concept (UN DESD, 2014). The UNECE Strategy for ESD continues through the 17 United Nations Sustainable Development Goals setting under SDG 4.7, launched in December of 2020 with an implementation horizon by 2030 (UN SDG 4.7, 2020).

One of the most decisive success, according to DESD was that of leadership. Leadership at regional, national, and local level is expected to be the factor that will create the necessary climate to accommodate future changes. To move towards the implementation of UN SDG 4.7 (2020), the school managers' role as managers is crucial. The role of the school manager goes beyond the managerial approach to a leadership approach. Under this prism, the school managers are expected to emphasize vision building and directions setting towards the environment. To achieve and fulfill a vision is a challenging task that requires all stakeholders' commitment (Kadji-Beltran et al. 2012).

In a study concerning the environmental behavior of secondary education students in Greece, most students $(80 \%)$ believed that school should participate in environmental activities such as recycling. At the same time, $2 / 3$ of them emphasize the school's important role in promoting their environmentally friendly behavior (Ntanos et al. 2018b). Therefore, the school manager's role is crucial in backing up such activities and introducing environmentally friendly activities in the school environment.

Furthermore, education is the second-largest consumer of energy in the service sector. Energy-efficient practices lead to essential energy savings since they can lead to significant energy consumption reductions because they are more controllable than other operating costs (Cingoski \& Petrevska, 2018). Therefore, it is crucial to explore the role of energy practices and behaviors at the educational units of all levels (Gormally et al. 2019).

The present paper employs a questionnaire survey on school managers, considering them as the school units' managers by using data for Greece's case. The analysis aimed to identify school managers' perceptions and behavior towards the environment and the application of energy-saving practices. Furthermore, the relation between the manager's ecologic awareness and the application of energy-saving practices is explored.

\section{Literature review}

About $40 \%$ of total final energy consumption and one-third of carbon dioxide emissions in Europe are attributed to the construction sector. Improving the energy efficiency in buildings at Europe is an important goal to achieve the EU targets for 2020 and 2030 and achieve the long-term goals set by the roadmap for a low-carbon economy (Kapsalis et al. 2019) and the SDG 4.7. By improving the energy efficiency of buildings, it is possible to reduce the EU's total energy consumption by 5 to $6 \%$, while reducing carbon dioxide emissions by around 5\% (Doukas et al. 2017). The EU has adopted several directives to improve its EU-Member States' energy efficiency and reduce its energy dependence, such as Directives 2012/27/EU and the latter 2018/2002/EU which updates the first Directive and extends its horizon up to 2030. Those Directives rotate around the energy saving obligations and the promotion of energy efficiency of the EU member states. Furthermore, emphasis is put on the need to mobilize investments towards renovating and upgrading the existing building stock to promote emissions reduction (EU, 2018). In particular, the reduction of buildings' energy consumption is one of the essential pillars of the broader goal to improve energy efficiency, which is evidenced by a series of provisions concerning the building sector (Doukas et al. 2017).

The final energy consumption in buildings depends on a) the type of building, b) the area in which it is located, c) the level of economic activity in the area where it is located and d) the modern way of life and the growing needs of people, including increased energy needs for ventilation and air conditioning systems (Maleviti et al. 2011; Maleviti et al. 2012). Improving energy efficiency in buildings enable decision-makers to make decisions by offsetting energy, finance, and other factors to make the right choice (Diakaki et al. 2013).

Directives 2010/31 / EU (Energy Efficiency Directive for Buildings-EPBD) and 2012/27 / EU (Energy Efficiency Directive - EED) refers to measurable policies that improve the European building stock's energy efficiency. Although the directives mentioned above have recently been amended by directives 2018/844 and 2018/2002, respectively, the main objective of the EPDB is near-zero energy buildings (nZEBs) for both new and renovated buildings. The almost zero or exceptionally low amount of energy required must be accomplished by an energy production portion from RES of localized availability (Pallis et al. 2019).

At an operational level, building performance is classified into technical, functional, behavioral, aesthetic, and environmental dimensions, covering a broad range of considerations that affect the local and global built environment (Bortolini \& Forcada, 2018). In such a context and concerning the energy aspect of a building, the most extensively used indicator is the energy consumption indicator (Lavy et al. 2010).

However, as research interest for energy performance in school buildings has been steady growing during the last decade, an earlier study stressed out that the core measurable indicators used to determine operational performance at buildings have become more pluralistic containing proper safety and assets working conditions, as for health and comfort, space functionality and energy performance (Bortolini \& Forcada, 2018). These indicators are considered reliable and widely appreciated sources for the better analysis of building performance and the definition of measures to improve performance during the operational phase of a building (Bortolini \& Forcada, 2018). Among the most agreed organizational policies of building performance is that of sustainability. Indeed, 
sustainability has become a relevant requirement for gaining legitimacy and improving the buildings' operation's success and directly impacting on environmental protection and energy efficiency in the built environment. Through sustainability managers would be benefited by taken into consideration a wide spectrum of advantages at extensive market knowledge and innovative tools (Nyuur et al. 2020).

School buildings are unique and special types of buildings. Its successful operation depends on many parameters such as: visual comfort, reflection, indoor quality, air quality, lack of colours or not, uniformity of lighting, the satisfaction of teaching staff, ventilation, how lighting affects children's behavior, the orientation of the building and the energy consumption. The almost zero energy building policy (nZEB) is vital for the EU and now applies to school buildings (Doulos et al. 2019). Pereira et al. (2014) examined energy consumption in school buildings and reported a range of primary energy consumption from $86 \mathrm{kWh} / \mathrm{m}^{2}$ to $272 \mathrm{kWh} / \mathrm{m}^{2}$ and a range of annual consumption reduction of electricity from $18 \mathrm{kWh} / \mathrm{m}^{2}$ to $66 \mathrm{kWh} / \mathrm{m}^{2}$. School buildings are significant to society since they serve more than 100 million students in Europe. However, in the design of school buildings, obtaining the right environment is often not considered a priority. Therefore, school buildings represent a significant part of the building stock and a significant percentage of total energy use. Existing school buildings often do not have systems that optimize energy consumption. In recent decades, several educational buildings have been built with respect for environmental protection and the rational use of energy (Zeiler \& Boxem, 2013).

School buildings also play a fundamental role in society, acting as sources of information for various groups. The activities undertaken in school buildings can benefit the school environment itself and reach the social and family circles of students and employees. Knowledge of energy consumption in these buildings can lead to practical actions to upgrade energy efficiency and promote a conscious culture of energy consumption in society. The analysis of energy efficiency in buildings is essential for comparing efficiency between technologies and determining consumption patterns. Energy efficiency analysis provides essential information for estimating future consumption and developing public policies on energy efficiency, which improves resource management (Geraldi \& Ghisi, 2020). The prominent role of school buildings changes towards the local societies and communities had also been proposed and determined in earlier research (Nollen et al. 2007; Kassim \& Abdullah, 2011).

Education campuses exhibit multiple favorable and unique attributes, such as access to capital, multiple stakeholders involved with differing needs, control of heterogeneous and energy-intensive buildings: laboratories, medical research facilities, sports facilities, and food services (Kim et al. 2019). Therefore, it is an excellent opportunity to conserve energy by retrofitting these buildings without necessarily understanding these decision-making processes when deciding among different factors such as economic feasibility, environmental impact, institutional characteristics, occupant impact, and technical practicality (Kim et al. 2019).
The previous relationship has been literature linked in an earlier study between creative behaviour and happiness at school buildings (Soleimani \& Tebyanian, 2011). These authors argued that creativeness, flexibility, and motivation could nurture a happy environment in school buildings. The critical aspects of such happiness nurture are of environmental and organizational orientation, including the lighting of the classrooms, the well designed and applicable heating, and cooling systems, the bright and light colours on the yard walls, classroom doors and windows as well as new green areas, all contributing to the improvement of happiness and schools' attractiveness. Such a happiness in school buildings can better motivate students' performance and indirectly influence their effectiveness, enabling teachers' perceptions of their manager's commitment and the managers' self-reported commitment to be significantly accomplished (Hart \& Willower, 1994; Soleimani \& Tebyanian, 2011). In this context, it is noteworthy that an effective manager leadership is not only studentsbeneficial, but it can keep teachers in disadvantaged schools, while positively affecting manager effectiveness to teacher satisfaction and turnover in hard-to-staff school environments (Grissom, 2011).

Energy efficiency is significant in school buildings related to the comfort and air quality conditions inside them while the energy cost of these buildings is related to their operating costs. Besides, school buildings are different from other buildings because they are places where children are educated and can learn how to become environmentally conscious citizens through growing awareness across Europe to promote sustainable solutions in school buildings that incorporate energy-efficient technologies and measures (Dimoudi \& Kostarela, 2009).

An important cornerstone of sustainable use of energy in school buildings has been achieved through the bioclimatic architecture. Bioclimatic architecture refers to buildings and spaces (interior - exterior - outdoor) design based on local climate, supporting a thermal and visual comfort, using efficiently and sustainably renewable sources of energy like solar, thermal, and wind energy sources. Bioclimatic architecture in school buildings should incorporate passive solar systems while utilizing environmental sources for heating, cooling and lighting the buildings. Passive and low energy schools save a significant amount of energy, reaching up to $70 \%$. Finally, the schools with the highest energy efficiency consume up to $50 \%$ less primary energy than the new buildings. The results are optimistic because they show immense potential for energy savings in municipalities by the building sector (Thewes et al. 2014). The tertiary sector buildings in which the school buildings are included should be friendly to the students satisfying their needs for learning, personal development, and self-realization. At the same time, they should be energy efficient (Zhang et al. 2017).

The role of energy efficiency is the prime goal of reducing environmental pressures. Energy efficiency is also co-existing in alignment with extensive energydepended organizations and resources' depletion. Interestingly, it has been methodologically investigated the empirical association of ethical and transformational leadership in influencing green creativity and ecoinnovation among Indonesia's educational institutes 
(Bahzar, 2019). This study denoted that eco-innovation and green capacity were significantly impacting energy efficiency in international schools in Indonesia. In jointly approaching green transformational leadership, ecoinnovation, and green creativity, it was proven their essential and significant contribution to enhancing energy efficiency in Indonesia's education sector. In such developing economies, it is also noteworthy that the central government needs to drive future governmental policies towards environmentally friendly innovations towards enhancing energy efficiency and reducing the ecological footprint (Bahzar, 2019). In an international context, green schools support the child to learn, and they are also nurturing suitable environments for leaders and teachers to flourish. Green schools are more inviting, more receptive to creativity, and more open to learning for educates while creating a positive environment for learning, challenging students to be engaged with personal or social significance issues. School managers can accomplish green school through problem-based learning strategies and addressing environment; yet, balancing between creativity and cooperation is critical to green schools' effective operation (Lemoine et al. 2014).

Considering the above information there is excellent potential for Greek school buildings (Tsikra \& Andreou, 2017). School Managers as school leaders play an essential role in energy efficiency since they are responsible for supporting teachers, staff and students and handling various everyday problems. They also act as building managers since they are responsible for solving everyday problems, promoting and guiding energy conservation, and proposing building upgrades to the authority. The significant role of managers towards energy sustainability in the case of hotel buildings is discussed in the study of Shehu et al. (2019). This study concluded that proper maintenance of the building and staff encouragement are significant towards improving energy saving.

Furthermore, a weak correlation was found between building managers' environmental perceptions and applying environmental management strategies (Shehu et al. 2019). According to Sardianou (2008), "the factors that hinder energy efficient investments are financial constraints, economic parameters, market imperfections, and organizational and human related factors". Among those factors, the human factor plays a critical role.

In some cases, managers do not apply energy efficiency measures due to lack of information and reduced awareness of environmental problems. Furthermore, bureaucratic problems and financial constraints hold back the application of energy-efficient technologies. Therefore, according to Sardianou (2008), the diffusion of energysaving techniques should be human-related by investing in human capital.

Since 1977 the Organization of School Buildings (O.S.K. S.A.) was the sole entity in Greece to design and construct school buildings. Since 2013, where O.S.K. has ceased operations, KTYP S.A. is the single state-owned authority, responsible for constructing the nation's public buildings, such as hospitals, penitentiary facilities, and schools (KTYP, 2020). According to a study concerning Greek schools energy performance, in a sample of 500 schools, the average building age was 36.5 years, around $1 / 3$ of the school buildings were older than 40 years (Dascalaki \& Sermpetzoglou, 2011). The existing heating system was characterized as average while several cases of increased energy consumption and extensive energy use were reported.

\section{Methodology}

According to the Hellenic Statistical Authority building census of 2011 (ELSTAT, 2015), there were 21,853 school buildings in all education levels in Greece. According to data from OECD (2018), the school building from Kindergarten level up to upper secondary level for the year 2016 were 16,664 buildings, serving a total of $1,975,508$ students aged from 4 to 18 years old (Table 1 ).

The current study was based on a survey conducted between January and March 2018. The purpose of this survey was to determine the attitudes and behaviors of school managers regarding the use of RES in schools. An electronic questionnaire was used to collect the answers, which was configured with the Google Drive Forms application. The questionnaire for the current research consisted of 41 multiple choice questions on RES and energy behavior and 5 questions related to the survey's demographic data. The questions given to the school managers were divided into three sections: a) perceptions towards RES implementation, b) Energy saving habits in school environment and c) energy saving beliefs and environmental sensitivity. All questions were obligatory to respondents in order to be able to submit the electronic questionnaire.

The research focused on school managers throughout Greece. It is important to clarify that for the case of Greece the role of the school manager is performed by the school principal who is also a teacher. So, a total of 10,745 emails were sent to managers of primary and secondary schools by using random sampling out of the population of 16664 schools. A total of 510 school managers answered the survey. The survey's overall response rate was $5.68 \%$.

Table 1

Number of school buildings and students (Data for Greece, 2016)

\begin{tabular}{lcc}
\hline & $\begin{array}{c}\text { Number of } \\
\text { Schools }\end{array}$ & $\begin{array}{c}\text { Number of } \\
\text { Students }\end{array}$ \\
\hline Kindergarten & 5,224 & 137,585 \\
Primary school & 4,566 & 604,497 \\
Secondary school & 3,437 & 617,280 \\
Lower secondary school & 1,747 & 296,865 \\
$\begin{array}{l}\text { Upper secondary } \\
\text { vocational school }\end{array}$ & 399 & 86,038 \\
$\begin{array}{l}\text { Upper secondary } \\
\text { general school }\end{array}$ & 1,059 & 230,239 \\
Other & 232 & 3,004 \\
Total & 16,664 & $1,975,508$ \\
\hline
\end{tabular}

Source: $O E C D(2018)$. 
The research methods included descriptive statistical analysis and also Friedman and $\chi^{2}$ tests with the statistical software of SPSS 20. By applying the Friedman test we initially ranked the items (higher ranking reveals a more positive response) and afterwards we proceeded with the classification of the items of each section by order of importance.

\section{Results}

\subsection{Sociodemographic characteristics of the respondents}

Concerning respondents' gender (Figure 1), 250 male school managers represented $49 \%$ of the sample size while 260 female respondents represented 51\%. Most of the respondents had a master's degree $(49.2 \%), 43.1 \%$ had a University Degree while 6.3\% also had a Ph.D.

As presented in Figure 2, most of the respondents in our sample (36.3\%) were serving at Primary School level, while a percentage of $22.9 \%$ were at Kindergarten level. A percentage of $21 \%$ were at Junior High Schools while $9.2 \%$ were at Senior High Schools. The other $10.6 \%$ were at Experimental, Vocational and Evening Senior High Schools.

The School managers had an average of 24.8 years of service in the educational sector with a standard deviation of 7.1 years. Most of the school managers had 25-30 years while a significant proportion had an experience for more than 30 years. The details about the total work experience in educational sector are included in Figure 3. Furthermore, the average service as school managers was 7.1 years with a standard deviation of 6 years.

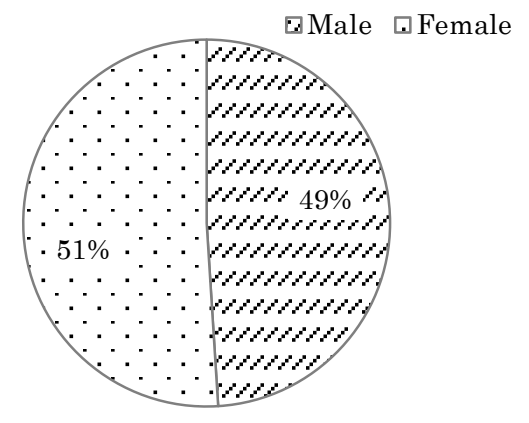

Fig. 1 School managers gender distribution

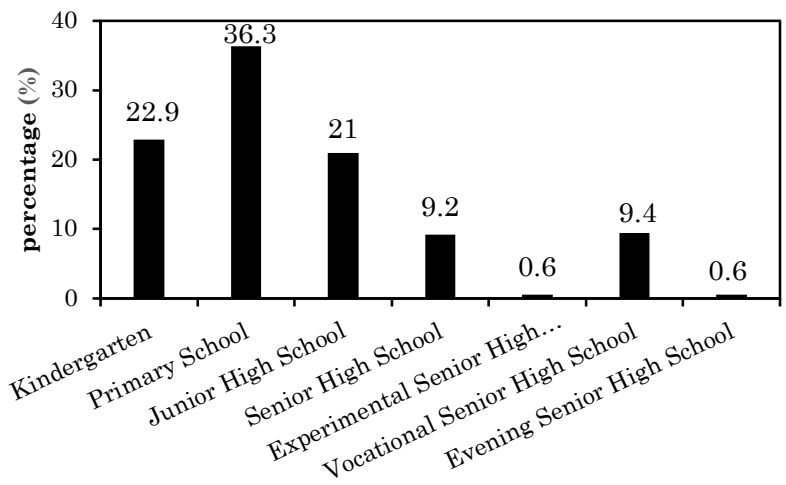

Fig. 2 School managers per educational unit

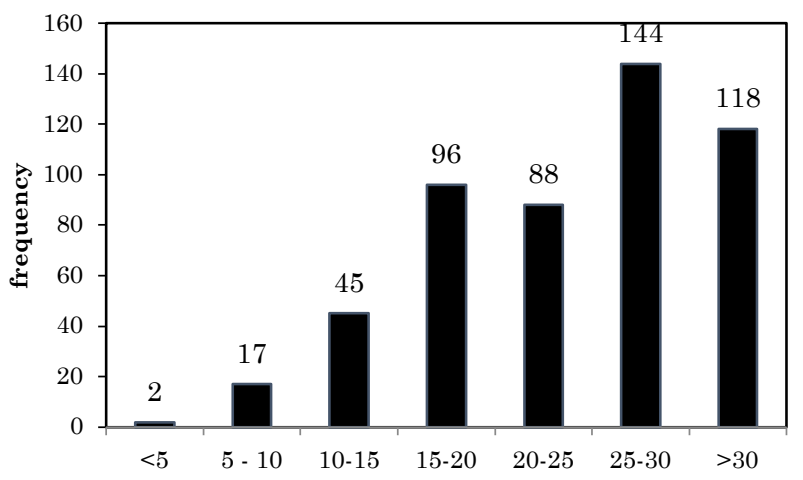

Fig. 3 School managers work experience in the educational sector

\subsection{RES and energy-saving implementation in the school environment}

In a question concerning the knowledge level of the school managers towards RES (Table 2), most respondents according to the categories of high or excellent knowledge reported to have good knowledge on solar energy (71.4\%), followed by knowledge on wind energy, (64.3\%). The least known RES source was biomass, with a percentage of $34 \%$ on the categories of high or excellent knowledge level.

On the other hand, most respondents, $90.4 \%$ reported that RES are used less in Greece compared to other EU countries. Moreover, most respondents $(81.2 \%)$ reported that the primary source of information on RES was the internet.

The importance of RES-oriented education and energy saving according to school managers' opinion was the topic of a multidisciplinary section including 10 questions, presented in Table 3. The questions mainly focused on the inclusion of renewable energy-oriented courses on the taught curricula, the importance of renewable energy education, and the role of parents, students, and instructors towards promoting energy saving. After applying the Friedman's test $\left(\chi^{2}=1053.23 \mathrm{df}=9\right.$ asymp. Sig=0.000), we ranked the questions and we sorted them by order of importance (from the most positive to the least positive responses) and we noticed that the most critical issue on this multidisciplinary variable was that "it is important to provide education in schools on RES", which had the highest Friedman's test mean rank of 7.19. More specifically, 73.9\% strongly agreed, 25.1 agreed, 0.6\% neither agreed nor disagreed while only $0.4 \%$ disagreed.

Table 2

Respondents self-reported knowledge level towards various RES forms

\begin{tabular}{llllll}
\hline RES Knowledge & None & Low & Medium & High & Excellent \\
\hline Wind & 0.8 & 9.2 & 25.7 & 30.0 & 34.3 \\
Solar & 0.4 & 6.3 & 22.0 & 31.2 & 40.2 \\
Hydro & 3.9 & 17.6 & 25.5 & 27.5 & 25.5 \\
Geo & 6.1 & 27.8 & 22.4 & 22.5 & 21.2 \\
Biomass & 10.4 & 30.8 & 24.9 & 17.5 & 16.5 \\
\hline
\end{tabular}


Table 3

School managers perceptions towards RES implementation and energy saving in school

\begin{tabular}{|c|c|c|c|c|c|c|}
\hline & $\begin{array}{l}\text { Strongly } \\
\text { Disagree }\end{array}$ & Disagree & Neutral & Agree & $\begin{array}{l}\text { Strongly } \\
\text { Agree }\end{array}$ & $\begin{array}{l}\text { Mean } \\
\text { Rank }\end{array}$ \\
\hline It is important to provide education in schools on RES & 0 & 0.4 & 0.6 & 25.1 & 73.9 & 7.19 \\
\hline More educational programs in schools on RES & 0 & 0.6 & 2.7 & 34.7 & 62 & 6.62 \\
\hline Courses should place more emphasis on RES & 0 & 0.4 & 4.1 & 35.7 & 59.8 & 6.48 \\
\hline $\begin{array}{l}\text { Teachers' community needs to raise awareness on } \\
\text { RES }\end{array}$ & 0 & 0.8 & 3.9 & 45.7 & 49.6 & 6.02 \\
\hline $\begin{array}{l}\text { Focus on RES and energy saving with in-service } \\
\text { training programs for teachers }\end{array}$ & 0 & 1.4 & 8.8 & 50.4 & 39.4 & 5.36 \\
\hline I have a role in saving energy in my school & 1 & 2.5 & 9.6 & 48.6 & 38.2 & 5.27 \\
\hline Insufficient programs in schools regarding RES & 0.2 & 3.9 & 13.9 & 46.3 & 35.7 & 4.97 \\
\hline $\begin{array}{l}\text { My colleagues have a role in saving energy at my } \\
\text { school }\end{array}$ & 1.6 & 4.1 & 14.7 & 46.3 & 33.3 & 4.82 \\
\hline Students have a role in saving energy in my school & 1.2 & 5.9 & 16.7 & 45.5 & 30.8 & 4.59 \\
\hline Parents have a role in saving energy at my school & 4.3 & 10.4 & 26.5 & 32.7 & 26.1 & 3.68 \\
\hline
\end{tabular}

Friedman test $\chi^{2}=1053.23 \mathrm{df}=9$ asymp. Sig $=0.000$

Table 4

Energy Saving Habits of School Managers in school environment

\begin{tabular}{|c|c|c|c|c|c|c|}
\hline & Never & Rarely & Often & Very Often & Always & $\begin{array}{l}\text { Mean } \\
\text { Rank }\end{array}$ \\
\hline $\begin{array}{l}\text { Do you turn off the lights when you leave } \\
\text { your classroom at the end of the lesson? }\end{array}$ & 0.6 & 1.8 & 5.3 & 11.8 & 80.6 & 4.66 \\
\hline $\begin{array}{l}\text { Do you close the windows when the air } \\
\text { conditioning is on in the school premises? }\end{array}$ & 2.2 & 1 & 4.9 & 16.1 & 75.9 & 4.52 \\
\hline $\begin{array}{l}\text { Do you close the windows when the heating } \\
\text { is on in the school premises? }\end{array}$ & 0.2 & 1.6 & 7.6 & 16.7 & 73.9 & 4.48 \\
\hline $\begin{array}{l}\text { Do you turn off the lights when you leave } \\
\text { your office for a lesson? }\end{array}$ & 2.2 & 5.7 & 12.7 & 18 & 61.4 & 3.95 \\
\hline $\begin{array}{l}\text { Do you turn off the lights when you leave } \\
\text { your classroom for a break? }\end{array}$ & 2.9 & 6.3 & 10.8 & 20.2 & 59.8 & 3.87 \\
\hline $\begin{array}{l}\text { Do you turn off the computer when you leave } \\
\text { your office? }\end{array}$ & 4.5 & 10.2 & 11.4 & 14.9 & 59 & 3.67 \\
\hline $\begin{array}{l}\text { Do you turn off the lights when you leave } \\
\text { your office for a short period? }\end{array}$ & 3.5 & 14.3 & 17.5 & 29.4 & 35.3 & 2.85 \\
\hline
\end{tabular}

Friedman test $\chi^{2}=477.23 \mathrm{df}=6$ asymp. sig $=0.000$

According to the respondents' opinion, the second most important issue was that "It is necessary to organize more educational programs in schools on the importance of renewable energy sources", with a mean rank of 6.62 on Friedman test, gathering a total of $96.7 \%$ on taahe categories of "strongly agree" and "agree". On the other hand, parents' role got the lowest mean rank of 3.68 with $58.8 \%$ on the categories of "strongly agree" and "agree".

\subsection{Energy saving habits in school}

Energy-saving habits in school include turning off lights when leaving the office or classroom, closing the windows when heating or air-condition is in operation and turning off the computer when leaving the office. After applying the Friedman's test we sorted the 8 questions of this section from the highest rank (more important) to the lowest rank (less important), as seen in the last column of Table 4. It was revealed that the most frequent energysaving habit is "turning off the lights when leaving the classroom", with a mean rank of 4.66, according to
Friedman test. Most of the educators $80.6 \%$ always turn off the lights at the end of the lesson. On the other hand, "turning off the lights when leaving the office for a short period" got the lowest mean rank of 2.85 .

\subsection{Environmental and Energy Saving Beliefs}

Concerning the school managers' environmental and energy-saving beliefs, we used a multidisciplinary variable containing 19 questions (Table 5). The questions were focused on common perceptions about the environment from the NEP Scale (Dunlap et al. 2000) and questions from Ntanos et al. (2018a, b). After performing the Friedman's test the most critical issue according to the managers is that "The harmonious coexistence of people with the natural environment is a prerequisite for our survival", with a mean rank of 13.37 . There was $89.4 \%$ of the respondents that strongly agreed and $10.4 \%$ that agreed. The second most important issue was "There is a need for the gradual replacement of conventional forms of energy, e.g., oil and there is a need to use renewable 
energy sources", with a mean rank of 12.25 , having $76.3 \%$ on the strongly agree category and $21.6 \%$ on the agree category. On the other hand, the question "I am willing to pay more to get clean energy in my home", has the lowest mean rank of 4.14

Table 5

School managers energy saving beliefs and environmental sensitivity

\begin{tabular}{|c|c|c|c|c|c|c|}
\hline $\begin{array}{l}\text { School Managers Environmental and Energy Saving } \\
\text { Beliefs } \\
\text { (in \%) }\end{array}$ & $\begin{array}{l}\text { Strongly } \\
\text { Disagree }\end{array}$ & Disagree & Neutral & Agree & $\begin{array}{l}\text { Strongly } \\
\text { Agree }\end{array}$ & $\begin{array}{l}\text { Mean } \\
\text { Rank }\end{array}$ \\
\hline $\begin{array}{l}\text { The harmonious coexistence of people with the natural } \\
\text { environment is a prerequisite for our survival }\end{array}$ & 0 & 0 & 0.2 & 10.4 & 89.4 & 13.37 \\
\hline $\begin{array}{l}\text { Need for gradual replacement of conventional forms of } \\
\text { energy }\end{array}$ & 0.4 & 0.2 & 1.4 & 21.4 & 76.7 & 12.25 \\
\hline $\begin{array}{l}\text { I need to save energy for protecting the environment } \\
\text { and human health }\end{array}$ & 0 & 0.4 & 1.8 & 21.6 & 76.3 & 12.19 \\
\hline $\begin{array}{l}\text { Our main concern should be to encourage energy saving } \\
\text { efforts }\end{array}$ & 0 & 0.6 & 1.8 & 23.7 & 73.9 & 12.04 \\
\hline $\begin{array}{l}\text { The balance of nature is very sensitive and can be easily } \\
\text { disturbed }\end{array}$ & 0 & 0.2 & 2.5 & 25.3 & 72 & 11.79 \\
\hline $\begin{array}{l}\text { Greece has potentials to produce RES due to its location } \\
\text { and climatic characteristics }\end{array}$ & 0.4 & 0.4 & 5.9 & 26.9 & 66.5 & 11.11 \\
\hline I believe I have a role in saving energy in my home & 0.4 & 0.8 & 3.7 & 32.5 & 62.5 & 10.87 \\
\hline $\begin{array}{l}\text { The development of RES can enhance economic growth } \\
\text { in Greece }\end{array}$ & 0.6 & 1 & 10.4 & 39 & 49 & 10.73 \\
\hline $\begin{array}{l}\text { It is important in the process of globalization to inform } \\
\text { citizens about RES }\end{array}$ & 0 & 0.4 & 3.3 & 37.1 & 59.2 & 10.72 \\
\hline Energy produced from RES is cheap & 0.6 & 0.2 & 4.3 & 35.5 & 59.4 & 10.53 \\
\hline $\begin{array}{l}\text { Energy savings are a concern only for the government } \\
\text { (Reversed) }\end{array}$ & 55.7 & 38.4 & 2.5 & 1.6 & 1.8 & 10.27 \\
\hline RES are environmentally friendly & 0 & 0.8 & 8.6 & 32.5 & 58 & 10.24 \\
\hline $\begin{array}{l}\text { RES must be used effectively to address the rapid } \\
\text { growth of energy demand }\end{array}$ & 0.4 & 1.4 & 6.7 & 44.7 & 46.9 & 9.35 \\
\hline $\begin{array}{l}\text { The development of RES in Greece will create energy } \\
\text { independence in the long run }\end{array}$ & 0.6 & 0 & 4.5 & 33.9 & 61 & 9.24 \\
\hline $\begin{array}{l}\text { I will implement energy saving practices even if I do it } \\
\text { myself }\end{array}$ & 0.2 & 1.6 & 11.8 & 42 & 44.5 & 8.86 \\
\hline $\begin{array}{l}\text { There are enough energy reserves and there is no need } \\
\text { to worry about running out in the future (Reversed) }\end{array}$ & 33.7 & 48.6 & 10.2 & 5.3 & 2.2 & 7.72 \\
\hline RES are not used enough around the world & 0.6 & 3.9 & 14.3 & 48.4 & 32.7 & 7.67 \\
\hline The use of RES is increasing worldwide & 0.2 & 2.7 & 21.6 & 48 & 27.5 & 6.9 \\
\hline I am willing to pay more to get clean energy in my home & 6.3 & 15.1 & 32 & 33.3 & 13.3 & 4.14 \\
\hline
\end{tabular}

Friedman test $\chi^{2}=2340.95 \mathrm{df}=18$ asymp. sig $=0.000$

Table 6

Results of $\chi^{2}$ test between school managers environmental beliefs and energy saving behavior

\begin{tabular}{|c|c|c|c|c|c|c|c|c|}
\hline & & & \multicolumn{5}{|c|}{$\begin{array}{c}\text { Do you turn off the lights when you leave your classroom at the } \\
\text { end of the lesson? }\end{array}$} & \multirow[b]{2}{*}{ Total } \\
\hline & & & Never & Rarely & Often & Very Often & Always & \\
\hline \multirow{6}{*}{$\begin{array}{l}\text { The harmonious } \\
\text { coexistence of people } \\
\text { with the natural } \\
\text { environment is a } \\
\text { prerequisite for our } \\
\text { survival }\end{array}$} & \multirow{2}{*}{ Neutral } & Count & 0 & 0 & 1 & 0 & 0 & 1 \\
\hline & & ExpecCount & .0 & .0 & .1 & .1 & .8 & 1 \\
\hline & \multirow{2}{*}{ Agree } & Count & 0 & 3 & 6 & 12 & 32 & 53 \\
\hline & & ExpecCount & .3 & .9 & 2.8 & 6.2 & 42.7 & 53 \\
\hline & \multirow{2}{*}{$\begin{array}{l}\text { Strongly } \\
\text { Agree }\end{array}$} & Count & 3 & 6 & 20 & 48 & 379 & 456 \\
\hline & & Expec Count & 2.7 & 8.0 & 24.1 & 53.6 & 367.5 & 456 \\
\hline \multirow{2}{*}{ Total } & & Count & 3 & 9 & 27 & 60 & 411 & 510 \\
\hline & & Expec Count & 3.0 & 9.0 & 27.0 & 60.0 & 411.0 & 510 \\
\hline
\end{tabular}

Pearson $\chi^{2}=36.63 \mathrm{df}=8$ asymp.sig $=0.000$ 


\subsection{Hypothesis testing}

Continuing the analysis, we used the question "the harmonious coexistence of people with the natural environment is a prerequisite for our survival" which had the highest mean rank according to the Friedman test of section 4.4 and the question "Do you turn off the lights when you leave your classroom at the end of the lesson?" with the highest rank in section 4.3 . So, by using the most crucial items by order of importance from the questionnaire sections of " 4.4 Environmental and Energy Saving Beliefs" and "4.3. Energy saving habits in school" we continued the analysis by applying a $\mathrm{x}^{2}$ test.

The null and alternative hypotheses were:

$\mathrm{H}_{0}$ : The environmental and energy saving beliefs are not related to environmental behavior such as turning off the lights when leaving the classroom.

$\mathrm{H}_{1}$ : The environmental and energy saving beliefs are related to environmental behavior such as turning off the lights when leaving the classroom.

Results are included in Table 6.

According to the results of the Pearson $\chi^{2}$ test $(\mathrm{sig}=0.000)$, $\mathrm{H}_{0}$ is rejected and $\mathrm{H}_{1}$ is accepted, therefore is a relationship between the school manager's ecological belief and the school environment's energy-saving habits. Managers that have a higher degree of environmental sensitivity are practicing energy saving behavior more systematically that those who have a lower level of environmental sensitivity.

By using the above approach we then used the question "it is important to provide education in schools on RES" which had the highest mean rank in section 4.2 and the question "The harmonious coexistence of people with the natural environment is a prerequisite for our survival" with the highest rank in section 4.4. We applied a second $\chi^{2}$ test to check whether the environmental beliefs are related with the importance of environmental education.

The null and alternative hypotheses were:

$\mathrm{H}_{0}$ : The importance of providing more RES education is not related to the ecological beliefs of the school manager.

$\mathrm{H}_{1}$ : The importance of providing more RES education is related to the ecological beliefs of the school manager.

The results of this $\chi^{2}$ test are included in the following Table 7.

According to the results of the Pearson $\chi^{2}$ test ( $\mathrm{sig}=0.000), \mathrm{H}_{0}$ is rejected and $\mathrm{H}_{1}$ is accepted, therefore we concluded that there is a relationship between the school manager's ecological belief and the importance of environmental education in the school environment. Managers that have stronger environmental beliefs and are more sensitive towards environmental issues seem to put more emphasis on providing RES education in schools.

Finally, we used $\chi^{2}$ tests to discover the relationship between the demographic variables of gender and word experience and the application of energy saving habits (see Table 4). The hypothesis test between the gender and the questions concerning energy saving habits in school (see Table 4) revealed the existence of a statistically significant relationship. More specifically female school managers are more consistent than their male counterparts in applying simple energy-saving habits in school environment, such as turning off the lights when leaving the classroom or turning off their computers when leaving their office. On the other hand, the hypothesis tests between the variables of the work experience in the educational sector and the application of energy saving behavior did not revealed a statistically significant relationship.

Table 7

Results of $\chi^{2}$ test between school managers environmental beliefs and perceived importance of providing more education on RES.

\begin{tabular}{|c|c|c|c|c|c|c|c|}
\hline & & & \multicolumn{4}{|c|}{$\begin{array}{c}\text { It is important to provide education in schools on renewable } \\
\text { energy sources }\end{array}$} & \multirow[b]{2}{*}{ Total } \\
\hline & & & Disagree & Neutral & Agree & $\begin{array}{l}\text { Strongly } \\
\text { Agree }\end{array}$ & \\
\hline \multirow{6}{*}{$\begin{array}{l}\text { The harmonious } \\
\text { coexistence of } \\
\text { people with the } \\
\text { natural } \\
\text { environment is a } \\
\text { prerequisite for our } \\
\text { survival }\end{array}$} & \multirow{2}{*}{ Neutral } & Count & 0 & 0 & 1 & 0 & 1 \\
\hline & & Expec Count & .0 & .0 & .3 & .7 & 1 \\
\hline & \multirow{2}{*}{ Agree } & Count & 0 & 3 & 31 & 19 & 53 \\
\hline & & Expec Count & .2 & .3 & 13.3 & 39.2 & 53 \\
\hline & \multirow{2}{*}{$\begin{array}{l}\text { Strongly } \\
\text { Agree }\end{array}$} & Count & 2 & 0 & 96 & 358 & 456 \\
\hline & & Expec Count & 1.8 & 2.7 & 114.4 & 337.1 & 456 \\
\hline \multirow{2}{*}{\multicolumn{2}{|c|}{ Total }} & Count & Count & 3 & 128 & 377 & 510 \\
\hline & & $\begin{array}{l}\text { Expec } \\
\text { Count }\end{array}$ & Expec Count & 3.0 & 128.0 & 377.0 & 510 \\
\hline
\end{tabular}

Pearson $\chi^{2}=67.29 \mathrm{df}=6$ asymp.sig $=0.000$ 


\section{Discussion}

The improvement of energy efficiency constitutes a core pillar of EU energy policy since it can satisfactorily serve the individual objectives, especially that of a) energy security for different types of energy consumption (businesses, industry, households), b) sequestration of carbon dioxide emissions, and c) the establishment of the necessary infrastructures to mitigate the effects of climate change from energy production schemes.

After adopting the Kyoto protocol on 1997 followed by the Paris Agreement on 2015, all EU countries are turning their energy production towards a greener profile, and energy consumption is stabilizing (The Paris Agreement, 2016). At the same time there are efforts to increase environmental sensitivity and awareness of people in order to further accept and adopt renewable energy practices (Stigka et al. 2016; Leontopoulos et al. 2015). A positive relationship was found between environmental knowledge and students' environmental attitudes (Pe'er et al. 2007). Within this framework, raising environmental awareness in the school environment is an important goal (Parant et al. 2017). In recent years, a continuous effort has been made for the rational management of energy and the enrichment of the energy mix using RES. In this context it is noteworthy the determining role of environmental awareness among managers at energy companies towards investing in energy-saving technologies, thus further contributing to the broader penetration of RES (Tsagarakis et al. 2012; Zografakis et al. 2012).

Those previous literature-based findings are compatible with the results of this study, since we found that the environmental awareness of school managers is related to practicing everyday energy-saving habits in school environmental and also to the conceptualization of the important role of environmental education.

Moreover, the reduction of energy consumption and energy use from RES in the building sector and especially in school buildings are essential measures required to reduce greenhouse gas emissions. In this context, teachers and especially the school units' "principals" (which are the school units' "managers" for our sample), can play a determining role in reducing energy production by using energy from RES in the school buildings. More specifically, the school unit managers are devoted to a vital role in the functionality, energy-saving, and RES implementation of a school building as they hold a position of institutional responsibility. Therefore, their attitudes, views and managerial abilities can further contribute to achieving the above. In the relevant literature it has been argued that most school principals are not systematically committed towards conceptualization of sustainable development through its implementation route of the Eco School, whereas they have focused mainly on everyday business but not frequently instilling environmental behavior. Therefore, it is crucial school principals, as managers, to adopt a role model for all school members: teachers, administrative staff, students, provoking changes in school culture and their eco-friendly directions and acknowledge the importance of the role of the family (Desfandi et al. 2016). According to the previous findings we discovered that less emphasis is put on the role of students and parents towards energy-saving in school. This is an important finding that reveals a potential lack of the school managers perceptions concerning the family role in shaping the environmental consciousness of the students which are also family members.

In our analysis we also discovered that school managers often apply simple energy-saving habits in school environment and have realized the need for more environmental education programs in school. The school managers of our analysis have an overall positive view towards the more systematic implementation of RES and energy-saving practices in school environment. The items that the managers placed high importance reveal that the managers understand the need for raising the awareness on RES by providing more RES-oriented educational curricula and education programs. Furthermore, there is a strong perception that teachers should also be more education on RES.

It is generally accepted that energy conservation and reductions in energy consumption are expected if an energy efficiency plan would be implemented. Such a plan must comply with the following research and managerial targets (Soares et al. 2015):

Energy planners and managerial strategies must be integrated into a "good practices guide" on energy efficiency and energy management.

Aim for joint efforts to engage students, faculty, and technical staff together on assessing of the energy efficiency of their specific studying/working buildings.

Based on the research findings over the last decade of publication, the effective operation of energy projects in the education systems has proven to be particularly beneficial because of the appreciably credible transfer of knowledge involving innovative technologies. At the same time environmental awareness is able to support the sustainable development, in alignment with measurable policies of energy saving and the importance of educating teachers about RES. Indeed, teachers who have accumulated sufficient knowledge and are aware of RES can better communicate their students' ways under which to acquire knowledge and adopt personal values that are impacting on their environmental awareness (Guven and Sulun, 2017). Subsequently, the connectivity developed between energy projects and education system it is proven invaluable to adopt innovative approaches while solving environmental problems (Ntona et al. 2015).

Social implications are pronouncing at education functions to educate the next generation of professionals for a sustainable culture, alarming educational community towards the utmost importance priority of rational energy consumption to achieve energy efficiency at the school buildings (Soares et al. 2015). Social appreciation of energy education should also be inspired by programs developed on a social marketing-enhanced home energy education visit to encourage homeowner adoption of specific energy conservation measures. Participants of energy education in the experimental condition before an energy audit adopted more no cost and low-cost, one-time energy conservation changes, but the cannot invest more in domestic energy renovations or other costly changes, such as replacing inefficient appliances. Enhancing the effectiveness of extensionbased energy education programs is a critical precondition to the effective adoption of energy-saving practices (Caldwell et al. 2019). 
The social implications of such practices are also related to how school managers can instill social and cultural diversity in their school environment. The keyaspects of nurturing a sustainable school culture are linked to discovering ways students experience the multidenominational ethos. At the same time, academics and practitioners can concretely understand the importance of leadership in shaping school climate/infrastructure that promotes a sense of belonging for all the students (Faas et al. 2018). Another significant social implication reported at our study resides to the fact of gender differences in instilling biodiversity at schools. Since women are more involved than men, in secondary education teaching roles, women mean that they have specialized knowledge and differentiated priorities in different areas of biodiversity. Therefore, it is inferring that while both women and men have a lot to contribute to biodiversity and ecosystem management, biodiversity policy and programming in many contexts still offer fewer opportunities to build on women's specific roles and capacities compared to those of men. Such gender-based differences in priorities are not always addressed, thus, generating "gender gaps" perhaps due to assumptions that men's and women's priorities are the same. Gender gaps also underline socio-cultural norms that may hinder women's equal access to natural resources and decision-making related to them. Consequently, biodiversity policy and programming are also important entry points for women's empowerment, where women are supported to overcome gender gaps and fulfil their potential - including to promote biodiversity goals (Chakrabarti 2020).

Electricity consumption reacts to its long-term equilibrium level by exhibiting an upward trend due to the development and expansion of secondary education. Besides, it can be denoted that educational development exerts a positive and significant growth impact on electricity consumption, thus, inferring that educational development plays a decisive role in energy consumption at short-term and long-term (Katircioglu, 2014).

\section{Conclusions}

According to the results of our study, school managers prioritize the need to provide environmental education in school. Furthermore, school managers strongly believe that there is a need to replace traditional energy sources with RES and seem environmentally sensitive. They also believe that they must emphasize on environmental protection. Hypothesis tests revealed a relationship between the school managers level of environmental awareness and the application of energy saving behavior such as the habit of turning off classroom lights and at the same time a stronger support for the idea of providing more environmental education in the school environment. Furthermore, we noticed that there is a statistically significant difference between the application of energy saving behavior and gender since female managers were more sensitive towards environmental and energy saving issues.

The main drivers towards the focus of school managers perceptions on energy efficiency are residing in the fact that both technological advancements and broader penetration of RES to almost all energy-consuming domestic sectors is high as more than ever before. These technological advancements are associated with citizens' high environmental consciousness, adopting everyday practices and habit of energy-saving and environmental respectfulness. In parallel, the main constraints of such a managerial perception reside in the fact that contemporary societies have instilled by different perceptions of how energy policies, motives, regulations and principles could be better fitting to the everyday life, customs and cultures. We should emphasize that the investigated school managers' perceptions are primarily human to human anthropocentric principles. Their effective adoption in the future cannot be a solely technical issue, but a humanitarian-driven endeavor, which will apparently challenge any future energy planning in national or international contexts of analysis.

The current research results can be used at the school level to contribute to the continuous improvement of their operating conditions in general and the further use of RES. These improvements are largely based on the school manager perception. Focusing on promoting the environmental awareness of school managers can be a significant driver towards greenifying the education facilities since managers are the people who cultivate and inspire the application of environmentally friendly practices. Indeed, the school manager is also the person having the responsibility to undertake the launch such environmental and energy education programs for all school teachers and students, as well as to motivate all central governmental incentives offered to improve the energy efficiency of school buildings.

Furthermore, more emphasis should be put on the important role of the family towards shaping the environmental attitudes of students and the collaboration between the school and the families.

Energy upgrading at school buildings can be notable since this sector is responsible for a significant proportion of energy demand among public buildings. Moreover, this sector can stimulate economic activity and enhance community employment. Other benefits are the improvement of living conditions among teachers and students which, in turn, can improve the learning process. Finally, there are measurable environmental benefits mainly regarding the reduction of both GHGs emissions and imported fuel for energy uses at the construction sector.

Further research can focus on the human assets of a school unit, including teachers and students and also students families, by disclosing their behavioural attitudes and personal stances on the topics of energy saving and energy efficiency among their school unit, especially in the light of RES contribution to the smooth functioning of all school unit activities/services/procedures.

\section{References}

Alwis, A. Acharya, B., Adhikari, S. (2021). Household energy consumption and adaptation behavior during crisis: Evidence from Indian economic blockade on Nepal. Energy Policy, 148, Part B, 111998

Bahzar, M. (2019). Effects of green transformational and ethical leadership on green creativity, eco-innovation and energy 
efficiency in higher education sector of Indonesia. International Journal of Energy Economics and Policy 9(6), 408-414. DOI: 10.32479/ijeep.8372.

Belaïd, F., Zrelli, M. H. (2019). Renewable and non-renewable electricity consumption, environmental degradation and economic development: Evidence from Mediterranean countries, Energy Policy, 133, 110929.

Bortolini, R., Forcada, N. (2018). Facility managers' perceptions on building performance assessment. Frontiers of Engineering Management, 5(3): 324-333.

Caldwell, K.A., Vaughn, L.A., Harrod, E., Harrod, J. (2019). Social marketing-enhanced home energy education encourages adoption of energy-saving practices. Journal of Extension, 57(5), 5RIB3.

Chakrabarti, S. (2020). Addressing Gender Issues and Actions in Biodiversity Objectives. Convention on Biological Diversity, Secretariat of the Convention on Biological Diversity, World Trade Centre, Canada, 54 pp. Open access $<$ https://www.cbd.int/gender/doc/cbd-towards2020gender integration-en.pdf $>$

Cingoski, V., Petrevska, B. (2018). Making hotels more energy efficient: the managerial perception. Economic ResearchEkonomska Istraživanja, 31(1), 87-101, DOI:10.1080/1331677X.2017.1421994

Cotton, D.R.E., Miller, W., Winter, J., Bailey, I., Sterling, S. (2015). Developing students' energy literacy in higher education. International Journal of Sustainability in Higher Education, 16 (4), 456-473. DOI: 10.1108/IJSHE-12-20130166.

Dascalaki, E, Sermpetzoglou, V. (2011). Energy performance and indoor environmental quality in Hellenic schools. Energy and Buildings. 43; 718-727.

Desfandi, M., Maryani, E., Disman (2016). The Role of School Principal Leadership in Implementation of Eco School Program as the Effort to Support Sustainable Development. Advances in Economics, Business and Management Research 14, 197-200. 10.2991/icemal-16.2016.40.

Diakaki, D., Grigoroudis, E., Kolokotsa, D. (2013). Performance study of a multi-objective mathematical programming modelling approach for energy decision-making in buildings. Energy, 59, 534-542.

Diakoulaki, D. (2014). Energy sector in Greece in an crisis epoch: Challenges and Perspectives [in Greek] Available at: https://www.hba.gr/5Ekdosis/UplPDFs/sylltomos14/291304\%20Diakoulaki\%202014.pdf

Dimoudi, A., Kostarela, P. (2009). Energy monitoring and conservation potential in school buildings in the C' climatic zone of Greece. Renewable Energy 34(1), 289-296.

Doukas, H., Malamatenios, X., Gkonis, N. (2017). European policies on energy savings and buildings renovation. Energy and Environment [In Greek]. Available at: https://www.alunet.gr/2017/01/4351v3

Doulos, L.T., Kontadakis, A., Madias, E.N., Sinou, M., Tsangrassoulis, A. (2019). Minimizing energy consumption for artificial lighting in a typical classroom of a Hellenic public school aiming for near Zero Energy Building using LED DC luminaires and daylight harvesting systems. Energy \& Buildings 194, 201-217

Dunlap, R., Van Liere, K., Mertig, A., Jones, R. (2000). New Trends in Measuring Environmental Attitudes: Measuring Endorsement of the New Ecological Paradigm: A Revised NEP Scale. Journal of Social Issues 56, 425-442.

ELSTAT (2015). 2011 Building Census, Tables 2 and 3., Hellenic Statistical Authority, https://www.statistics.gr/documents/20181/1204358/A1601_S KT01_DT_DC_00_2011_01_F_EN.pdf/4220d253-851c-43bda1e8-06b83ee6f309

EU (2018). Directive 2018/2002 of the European Parliament and of the Council. Available at: https://eur-lex.europa.eu/legalcontent/EN/TXT/PDF/?uri=CELEX:32018L2002\&from=EN

Faas, D., Smith, A., Darmody, M. (2018). The role of principals in creating inclusive school environments: insights from community national schools in Ireland. School Leadership and Management, $38 \quad$ (4), 457-473. $\quad$ DOI: 10.1080/13632434.2018.1430688.

Geraldi, M.S., Ghisi, E. (2020). Mapping the energy usage in Brazilian public schools. Energy and Buildings. 224, 110209.

Gormally, A.M., O'Neill, K., Hazas, M.D., Bates, O.E.G., Friday, A.J. (2019). 'Doing good science': The impact of invisible energy policies on laboratory energy demand in higher education. Energy Research and Social Science, 52, 123-131. DOI: $10.1016 /$ j.erss.2019.02.012.

Grissom, J.A. (2011). Can good principals keep teachers in disadvantaged schools? Linking principal effectiveness to teacher satisfaction and turnover in hard-to-staff environments. Teachers College Record, 113 (11), 2552-2585.

Guven, G., Sulun, Y. (2017). Pre-service teachers' knowledge and awareness about renewable energy. Renewable and Sustainable Energy Reviews, 80, 663-668.

Hart, D.R., Willower, D.J. (1994). Principals' Organizational Commitment and School Environmental Robustness. Journal of Educational Research, 87(3), 174-179. DOI: 10.1080/00220671.1994.9941239.

Kadji-Beltran, Ch., Zachariou, A., Stevenson, R. (2012). Leading sustainable schools: Exploring the role of primary school principals. Environmental Education Research 19, 1-21. DOI: 10.1080/13504622.2012.692770.

Kapsalis, V.C., Kyriakopoulos, G.L., Aravossis, K.G. (2019). Investigation of ecosystem services and circular economy interactions under an inter-organizational framework. Energies, 12 (9), 1734. DOI: 10.3390/en12091734.

Kassim, J.M., Abdullah, J.B. (2011). Promoting learning environment and attitude towards change among secondary school principals in pahang Malaysia: Teachers' perceptions. Procedia - Social and Behavioral Sciences, 28, 45-49. DOI: 10.1016/j.sbspro.2011.11.009.

Katircioglu, S.T. (2014). Estimating higher education induced energy consumption: The case of Northern Cyprus. Energy 66, 831-838. DOI: 10.1016/j.energy.2013.12.040.

Kim, A.A., Sunitiyoso, Y., Medal, L.A. (2019). Understanding facility management decision making for energy efficiency efforts for buildings at a higher education institution. Energy and Buildings 199, 197-215. DOI: 10.1016/j.enbuild.2019.06.044.

KTYP (2020). KTYP Company profile. Available at: https://www.ktyp.gr/index.php?option=com_content\&view=a rticle\&id $=128 \&$ Itemid $=172 \&$ lang $=$ en

Lavy, S., Garcia, J. A., Dixit, M. K. (2010). Establishment of KPIs for facility performance measurement: Review of literature. Facilities 28(9), 440-464.

Leontopoulos, S., Arabatzis, G., Ntanos, S., Tsiantikoudis, S.Ch. (2015). Acceptance of energy crops by farmers in Larissa's Regional unit, Greece: a first approach. In: Proceedings of the 7th International Conference on Information and Communication Technologies in Agriculture, Food and Environment (HAICTA), Kavala, Greece, September, 2015, 17-20. Available at.ceur-ws.org/Vol-1498/HAICTA_2015.

Lemoine, P.A., Mense, E.G., Richardson, M.D. (2014). Green school principals: Making the connection among student achievement, healthy school environments, and project-based learning. Marketing the Green School: Form, Function, and the Future, 144-154. DOI: 10.4018/978-1-4666-6312-1.ch010.

Maleviti, E., Mulugetta, Y., Wehrmeyer, W. (2011). Environmental Attitudes and Energy Initiatives within the Hellenic Hotel Sector. R.J. Howlett, L.C. Jain, \& S.H. Lee (Eds.): Sustainability in Energy and Buildings, SIST 7, pp. 225-235. Available at: https://link.springer.com/chapter/10.1007/978-3-642-17387$5 \_23$

Maleviti, E., Mulugetta, Y., Wehrmeyer, W. (2012). Energy consumption and attitudes for the promotion of sustainability in buildings, International Journal of Energy Sector Management, 6(2), 213 - 227. Available at: http://dx.doi.org/10.1108/17506221211242077.

Nollen, N.L., Befort, C.A., Snow, P., Daley, C.M., Ellerbeck, E.F., Ahluwalia, J.S. (2007). The school food environment and 
adolescent obesity: Qualitative insights from high school principals and food service personnel. International Journal of Behavioral Nutrition and Physical Activity, 4, 18. DOI: 10.1186/1479-5868-4-18.

Ntanos, S., Kyriakopoulos, G., Arabatzis, G., Palios, V., Chalikias, M. (2018a). Environmental Behavior of Secondary Education Students: A Case Study at Central Greece. Sustainability 10(5), $1663 \mathrm{https://doi.org/10.3390/su10051663}$

Ntanos, S., Kyriakopoulos, G., Chalikias, M., Arabatzis, G., Skordoulis, M. (2018b). Public Perceptions and Willingness to Pay for Renewable Energy: A Case Study from Greece. Sustainability 10, 687. https://doi.org/10.3390/su10030687

Ntona, E., Arabatzis, G and Kyriakopoulos, G. (2015). Energy saving: Views and attitudes of students in secondary education. Renewable and Sustainable Energy Reviews, 46, 115 .

Nyuur, R., Brečić, R., Murphy, P. (2020). Managerial Perceptions of Firms' Corporate Sustainability Strategies: Insights from Croatia. Sustainability, 12(1):251.

OECD (2018). The Greek education system in context, in Education for a Bright Future in Greece, OECD Publishing, Paris. DOI: https://doi.org/10.1787/9789264298750-3-en

Pallis, P., Gkonis, N., Varvagiannis, E., Braimakis, K., Karellas, S., Katsaros, M., Vourliotis, P., Sarafianos, P. (2019). Towards NZEB in Greece: A comparative study between cost optimality and energy efficiency for newly constructed residential buildings. Energy and Buildings. 198, 115-137.

Parant, A., Pascual, A., Jugel, M., Kerroume, M., Felonneau, M. and Guéguen, N. (2017). Raising Students Awareness to Climate Change: An Illustration with Binding Communication, Environment and Behavior 49 (3), 339-353.

Pe'er, S., Goldman, D., Yavetz, B. (2007). Environmental Literacy in Teacher Training: Attitudes, Knowledge, and Environmental Behavior of Beginning Students, The Journal of Environmental Education, 39 (1) 45-59.

Pereira, L.D., Raimondo, S., Corgnati, P., da Silva, M.G. (2014). Energy consumption in schools - A review paper. Renew. Sustain. Energy Rev. 40, 911-922.

Sardianou, E. (2008). Barriers to industrial energy efficiency investments in Greece. Journal of Cleaner Production, 16(13), 1416-1423, https://doi.org/10.1016/j.jclepro.2007.08.002.

Shehu, A.I., Inuwa, I.I., Husseini, I.U., Yakubu, I. (2019). Relationship of Hotel Energy Management Strategies and Hoteliers' Perception on Sustainable Energy Management in Abuja Nigeria. Resources and Environment, 9(1), 19-26. doi: 10.5923/j.re.20190901.03.

Soares, N., Pereira, L.D., Ferreira, J., Conceição, P., da Silva, P.P. (2015). Energy efficiency of higher education buildings: A case study. International Journal of Sustainability in Higher Education, 16 (5), 669-691. DOI: 10.1108/IJSHE-11-20130147.
Soleimani, N., Tebyanian, E. (2011). A study of the relationship between principals' creativity and degree of environmental happiness in Semnan high schools. Procedia - Social and Behavioral Sciences, 29, 1869-1876. DOI: 10.1016/j.sbspro.2011.11.436.

Stigka, E., Paravantis, J., Mihalakakou, G. (2014). Social acceptance of renewable energy sources: A review of contingent valuation applications. Renewable and Sustainable Energy Reviews 32, 100-106.

The Paris Agreement (2016). Work programme under the Paris Agreement [internet], http://unfccc.int/paris_agreement/items/9485.php

Thewes, A., Maas, S., Scholzen, F., Waldmann, D., Zürbes, A. (2014). Field study on the energy consumption of school buildings in Luxembourg, Energy and Buildings 68, 460-470. DOI: 10.1016/j.enbuild.2013.10.002

Tsagarakis, K., Karyotakis, K., Zografakis, N. (2012). Implementation conditions for energy saving technologies and practices in office buildings: Part 2. Double glazing windows, heating and air-conditioning. Renewable and Sustainable Energy Reviews, 16(6), 3986-3998

Tsikra, P., Andreou, E. (2017). Investigation of the Energy Saving Potential in Existing School Buildings in Greece. The role of Shading and Daylight Strategies in Visual Comfort and Energy Saving, Procedia Environmental Sciences 38, 204-211. DOI: 10.1016/j.proenv.2017.03.107.

UN DESD (2014). Shaping the Future We Want. DESD Monitoring and Evaluation UN Decade of Education for Sustainable Development (2005-2014) Final Report. Paris:

UN SFG 2.7 (2020). A Mission to transform education: UNESCO \& leading partners launch a global initiative to achieve SDG 4.7. Available at: https://en.unesco.org/news/missiontransform-education-unesco-leading-partners-launch-globalinitiative-achieve-sdg-47

UNECE (2005). UNECE strategy for ECE. Available at: https://unece.org/DAM/env/documents/2005/cep/ac.13/cep.ac. 13.2005.3.rev.1.e.pdf

United Nations Educational, Scientific and Cultural Organization. https://unesdoc.unesco.org/ark:/48223/pf0000230171

Zeiler, W., Boxem, G. (2013). Net-zero energy building schools. Renewable Energy 49, 282-286.

Zhang, A., Bokel, R., van den Dobbelsteen, A., Sun, Y., Huang, Q., Zhang, Q. (2017). Optimization of thermal and daylight performance of school buildings based on a multi-objective genetic algorithm in the cold climate of China. Energy and Buildings 139, 371-384.

Zografakis, N., Karyotakis, K., Tsagarakis, K. (2012). Implementation conditions for energy saving technologies and practices in office buildings: Part 1. Lighting. Renewable and Sustainable Energy Reviews, 16(6), 4165-4174 